\title{
Use of Medicinal Plant and Its Vulnerability Due to Climate Change in Northern Part of Bangladesh
}

\author{
Sadhan Kumar Roy ${ }^{1}$, Dipak Kumar Roy ${ }^{2}$ \\ ${ }^{1}$ Department of Geography and Environmental Science, Faculty of Life and Earth Sciences, Begum Rokeya University, Rangpur, \\ Bangladesh \\ ${ }^{2}$ Department of Public Health, School of Health \& Life Sciences, North South University, Dhaka, Bangladesh \\ Email: roysadhanges@gmail.com,dipakroyu@gmail.com
}

How to cite this paper: Roy, S.K. and Roy, D.K. (2016) Use of Medicinal Plant and Its Vulnerability Due to Climate Change in Northern Part of Bangladesh. American Journa of Plant Sciences, 7, 1782-1793.

http://dx.doi.org/10.4236/ajps.2016.713166

Received: August 1, 2016

Accepted: September 13, 2016

Published: September 16, 2016

Copyright $\odot 2016$ by authors and Scientific Research Publishing Inc. This work is licensed under the Creative Commons Attribution International License (CC BY 4.0).

http://creativecommons.org/licenses/by/4.0/ (c) (i) Open Access

\begin{abstract}
Medicinal plants are playing an important role to human livelihood. Bangladesh is well recognized of medicinal plants wealth as unique and globally rich. The studies demonstrate about the value of traditional systems of medicine as economically useful plants and possible effects of climate change on medicinal plants. It is true that climate change is causing noticeable effects on life cycles and distribution of the plant species. However, climate change effects on medicinal plants are widely unclear in Bangladesh. At present, a huge number of populations in Bangladesh are directly dependent on the healthcare treatment by medicinal plants that is why it is an emerging concern in Bangladesh. It is a crying need to improve our understanding the effects on medicinal plants by various researches is stressed in the present article. To know the present condition of medicinal plants and effects of climate change on medicinal plants in northern part of Bangladesh an attempt is being taken here. The study also added the optimum use of medicinal plants and their conservation in northern part of Bangladesh.
\end{abstract}

\section{Keywords}

Climate Change, Drought, Medicinal Plants, Conservation

\section{Introduction}

A medicinal plant is any plant which in one or more of its organs contains substance that can be used for therapeutic purposes or which are precursors for synthesis of useful drugs. Nowadays, man has always been interested in floral drugs to alleviate sufferings 
and diseases where it was started at the very beginning of human civilization. Because they are considered green medicine is always supposed to be safe. Total $80 \%$ of the world populations rely on traditional health care system [1]-[3]. The villagers maintain traditional knowledge of medicinal plants that they use for first aid remedies [4]. Medicinal plants serve as therapeutic agents as well as important raw materials for the manufacture of traditional and modern medicine. The system of ethno-medicine is safe and is a low cost therapy for treating various ailments [5]. The formal systems of plant medicine development are particularly found in China, India, Arabia, Egypt and Europe. Ayurveda system of herbal medicine in India, Sri Lanka and Southeast Asia used 8000 and Unani system in Pakistan is also largely plant based about 5000 out of China's total flora of 30,000 species are used in traditional Chinese medicine. Around 35,000 - 70,000 of the 250,000 species of higher plant has been used for medicinal purposes [3]. Medicinal plant constitutes an important neutral wealth of a country and plays a significant role of an economy of a country. They make an essential contribution to human health care provide livelihood to tribal and rural people. Moreover, they are also being used as raw materials in pharmaceutical industries. The primary health care of more than $60 \%$ population of Bangladesh especially of tribal and rural people and livelihoods depends greatly on medicinal plants wealth.

Climatic variables are strong environmental control of plant [6] [7]. Like all living members of biosphere, climate change is affects the life cycle and distributions of medicinal and aromatic plants (MAPs). These changes are likely to affect plant ecology e.g. drought and heat wave effects on photosynthesis, respiration, transpiration etc. [8]-[10] and increase plant mortality and extinction risk in many areas [10]. Species Distribution Modeling (SDM) is widely used for ecological applications [11] predicting and estimating potential effects of climatic change and guiding for conservation planning [12] [13]. Some studies demonstrated that temperature and wind action affecting precipitation factors which can affect the medicinal plant growth and activity as a result of ongoing climate change, many plant species are predicted to respond by shifting their ranges [14] or extinct in near future [15]. Due to climate change, some medicinal plants move to higher latitude and some medicinal plant becomes extinct [16].

Anthropogenic climate change effects on species and ecological communities around the world [17] and the cultivated medicinal plants also replaced many native ones. In the northern part of Bangladesh, people use different types of medicinal plants to treat different disease. Climate change is one cause for losing medicinal and aromatic plants in the northern part of Bangladesh. The region is also being negatively affected by deforestation and water scarcity unwise exploitation of land and rapid population growth.

\section{Data and Methodology}

Use of Medicinal Plant and its Vulnerability Due to Climate Change in Northern Part of Bangladesh is assessed based on the field observation, plant sample collection, questionnaire survey and formal and informal dialogue among the respondents in the selected area. 


\subsection{Study Area}

Kurigram district is situated in northern part of Bangladesh shown in Figure 1. Total area of this district is 2296.10 square kilometers and total land cover is about 276.45 square kilometers [18]. It is surrounded by Coach Bihar, West Bengal and Assam of India in North and East part. Gaibandha, Rangpur and Lalmonirhat district of Bangladesh is situated in South and Western part. Absolute location of this district is $25^{\circ} 23^{\prime} \mathrm{N}$ to $26^{\circ} 14^{\prime} \mathrm{N}$ latitude and $89^{\circ} 28^{\prime} \mathrm{E}$ to $89^{\circ} 54^{\prime} \mathrm{E}$ longitude shown in Figure 1 . It is 13 meter height from the mean sea level and here flows many small and big rivers. The climate of this district is tempered where there maximum temperature is $32.3^{\circ} \mathrm{C}$ and minimum $11.2^{\circ} \mathrm{C}$ (National Encyclopedia of Bangladesh, 2007). Her total annual rainfall is recorded is at about $2931 \mathrm{~mm}$. due to this type of climate here found various kinds of medicinal plants.

\subsection{Data Collection}

Since deforestation, environmental pollution, modern civilization and migrations of traditional medicinal healer to other jobs knowledge connected to ethno medicinal treatment are being seriously depleted and that could ultimately result in the rapid erosion of this rich knowledge. Moreover the knowledge on traditional practice of medi-

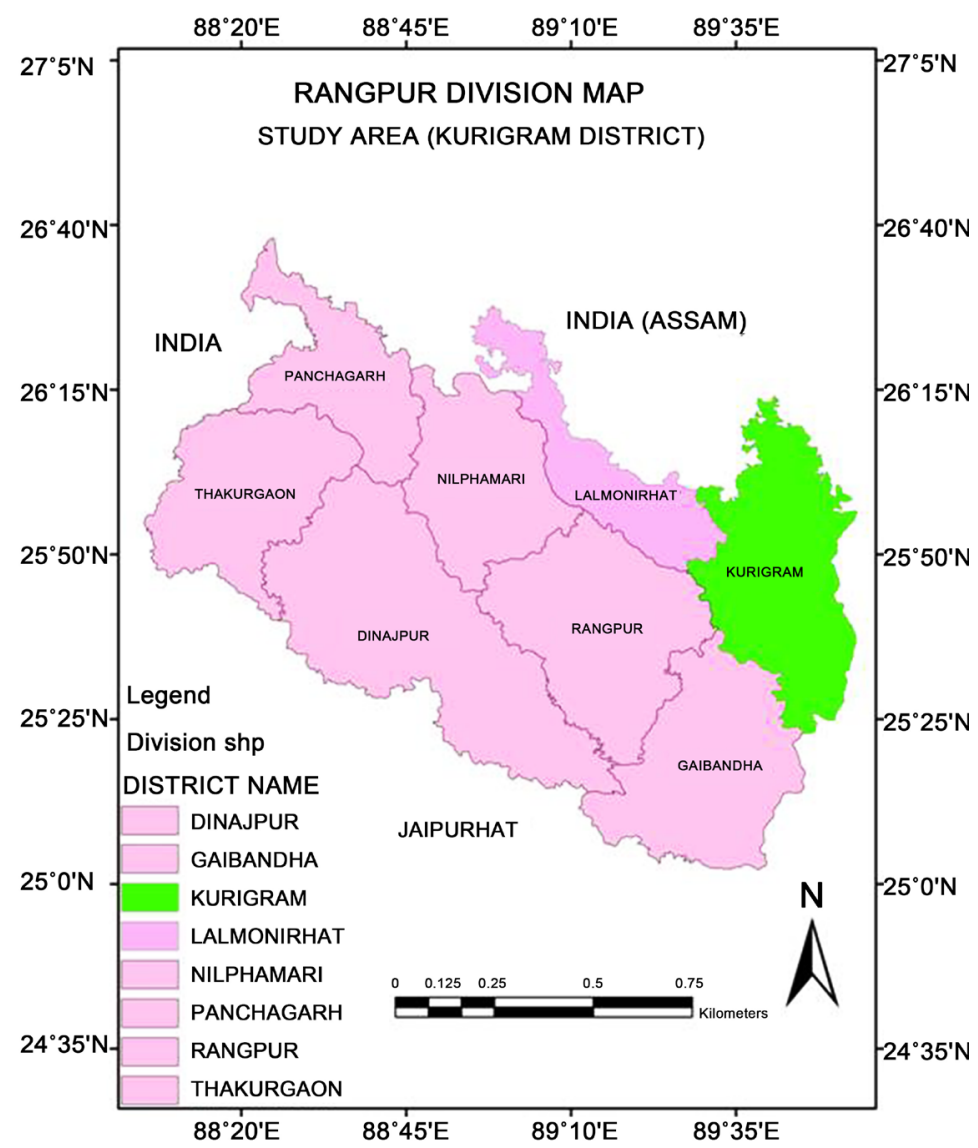

Figure 1. Study area map of kurigram district. 
cinal plants has been passed from one generation to next only verbally and most of the cases the written documents of this rich knowledge have not been available.

\subsection{Sampling of Informants}

During June 2014 to August 2015 the ethno pharmacological survey was conducted in the study area. Five days were conducted for consisting per field visit. Different community's interviewees were selected for the study purpose. The primary observation suggested that number distinct groups of people are involved and practiced medicinal plant to cure disease and traditional healing process in the study area as follows

- People of study area who are traditionally use medicinal plants by their indigenous knowledge getting from their previous generation.

- Local traditional health practitioners (Kobiraz literally in Bangla) who have practical and empirical knowledge on medicinal plant.

- A group of people or health practitioners having no formal education such as Bede, Sapure/ Ojha, and Dome etc. most of them are Hinduism.

\subsection{Determination of Sample Size}

In order to appropriate result of the study potentially significant group was sampled according to a sampling plan to that type of population. In this study sample size refers the number of subjects. These were sampled according to $95 \%$ confidence intervals using a Population Proportionate to Size (PPS) stratified plan considering study subjects. This suggested a sample size of the present study. On the basis of PPS sample size was allocated in various categories and sample was redistribution to ensure the minimum sample size required for any group. For fulfilling this purpose total 55 people were chosen from the selected group were interviewed. Gender, age, educational background and experience on use of traditional medicinal plants were taken into consideration during the selection of informants. Here was also collected the ethnographic data using observation, formal and informal dialogue and third person listening techniques. The formal interviews were prearranged, but informal opportunities were taken, at times and place were the participant's interest could be obtained and retained.

\subsection{Ethno-Medicinal Data Collection}

This study the explanation and written consent was obtained by interviewers from each informant. The people who are familiar with traditional healers and who could communicate with local communities are considered as participating respondent. To ensure confidentiality each informant was interviewed singly among them.

To collect knowledge and practice of medicinal plants in the study area a number of FGDs were also organized participated by 13 to 20 respondents who had given consent. Open ended and semi structural questionnaire was used for the purpose [19]. The record questionnaires used demographical information including age, sex, educational background and experiences of the healing related to medicinal plant and their practice including the local name of the plants, plants parts used, the methods of preparation, 
nature of plant materials, relative abundance at the area, habitat of the plant species, mode of applications and medicinal use of particular plants. Informants were asked to collect the plants they used for the treatment of various ailments. These specimens were pressed preserved and later identified. Some ethno medicinal data were collected from research articles, books and others were also studied. The compounds that were frequently found in the reported plant species were also documented.

\section{Result and Discussion}

\subsection{Informants}

At about 65 interviewees were done in the study area where the most of the informants were male and $70.8 \%$. There $48.8 \%$ informant's age was at about 55 - 65 years old. They were followed by informants with 45 - 55 years old and total percentage is $35.29 \%$. All of them are lived in the rural region and majority of them have no formal education. The rate of literacy of those people was lower $32.5 \%$ than other population in Bangladesh is $56.8 \%$ (BBS, 2012; CIA fact book, 2012). Majority of the respondents has $10-25$ years practical and empirical knowledge about the medicinal plant use and practice.

\subsection{Medicinal Plant Recorded}

During the study a total of 85 plant species belonging to 46 plant families were identified with medicinal values used by subject population in the study area. There Asteraceae family represents highest number of species more than 7, followed by Apocynaceae family represent only 6 species and Euphorbiaceae and Fabaceae only 5 species.

\subsection{Medicinal Plants in Bangladesh}

List of the medicinal plants of Bangladesh is below Table 1.

\subsection{Medicinal Plants Habitat of the Study Area}

In the current survey, $34 \%$ species were herb, $20.42 \%$ were shrub and $17.86 \%$ were tree. Among these plants $36.1 \%$ species grew in Plain land and crop land and $20.83 \%$ species were grown in surrounding the path of home. The habitat of plat species is shown in Table 2.

\subsection{Information Regarding the Preparation as Medicine}

Sometimes whole plants but many of the cases different parts of the same plants are used to produce medicine. The plant parts including producing various ailments are leaf, bark, root, flower, rhizome, seed, tuber, bulb and fruit. Most use of that part is leaf at about 59\%, followed by root 52\%, bark $13.1 \%$ and fruit $7.4 \%$ shown in Figure 2 . Various preparation methods are used for administering medicinal plants as their traditional practice including infusion, past, pills, syrup, smoke, juice, decoction and raw.

The major mode of preparation is juice $58.6 \%$ followed by decoction $37.8 \%$. Infusion is done by suspending plant material in either cold or pre-armed water and decoction is done by boiling or heating of plant material in water. Powder is obtained by finely 
Table 1. Available medicinal plant in Bangladesh.



Source: Anup Sadi 2012. 


\section{Parts of plants used in medicine preparation}

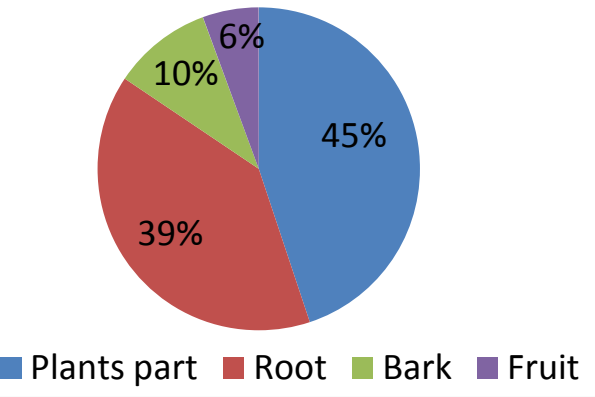

Figure 2. Parts of plants used in medicine preparation.

Table 2. The list of medicinal plants grows in different habitat in the study area.

\begin{tabular}{ccc}
\hline Plant group & Habitat & Local name of the plant \\
\hline $\begin{array}{c}\text { Plain land and } \\
\text { crop land plant }\end{array}$ & Plain land, & Kanibashi, Ghatekochu, Ghagra, Khadnli, \\
Surrounding the home & Having no water & Shialkhata, Dondokolosh, Kalomegh etc. \\
& & Bashok, Bohera, Akondo, Tharkrri, Talecochu, \\
& Chalta, Tulsi, Kuch, Punorvoba, Amloki etc.
\end{tabular}

grinding the plant parts to be used, after drying them. Juices are extracted from succulent plants. Most preparation is made with water as solvent. Other preparation are made by honey, ice soaked water and milk. Sometimes people used black pepper, salt, sugar, garlic, ghee, butter, banana leaf, turmeric, neem leaf, jackfruit leaf etc. as adjuvant with different solvents. For the preparation of paste or ointment they often used castor oil, coconut oil, ginger, mustard oil and neem. Oral ingestions were the most common mode of administration $93.4 \%$. Topical applications were also frequently employed; accounting for $54.6 \%$. For topical purpose, the most important methods used were direct application of paste. There found one inhalation.

\subsection{Medicinal Plant and Their Utility}

In the study area a large number of medicinal plants have identified by the ethno pharmaceutical survey. Table 3 shows the medicinal plants are found in the study area with mentioned their local and scientific name, usable part and use for disease cure and healing process.

\subsection{Formulation of the Medicine and Uses}

The study also identified the formulation of the medicine from the medicinal plants and their uses which will helpful for the natural healing process shown in Table 4 .

\subsection{Nearly Extinct Medicinal Plants in the Study Area}

There are a number of extinct medicinal plants have been identified in the study area. Some of them are presented in the Table 5. 
Table 3. List of identified medicinal plants in study area their using parts and use to control diseases.

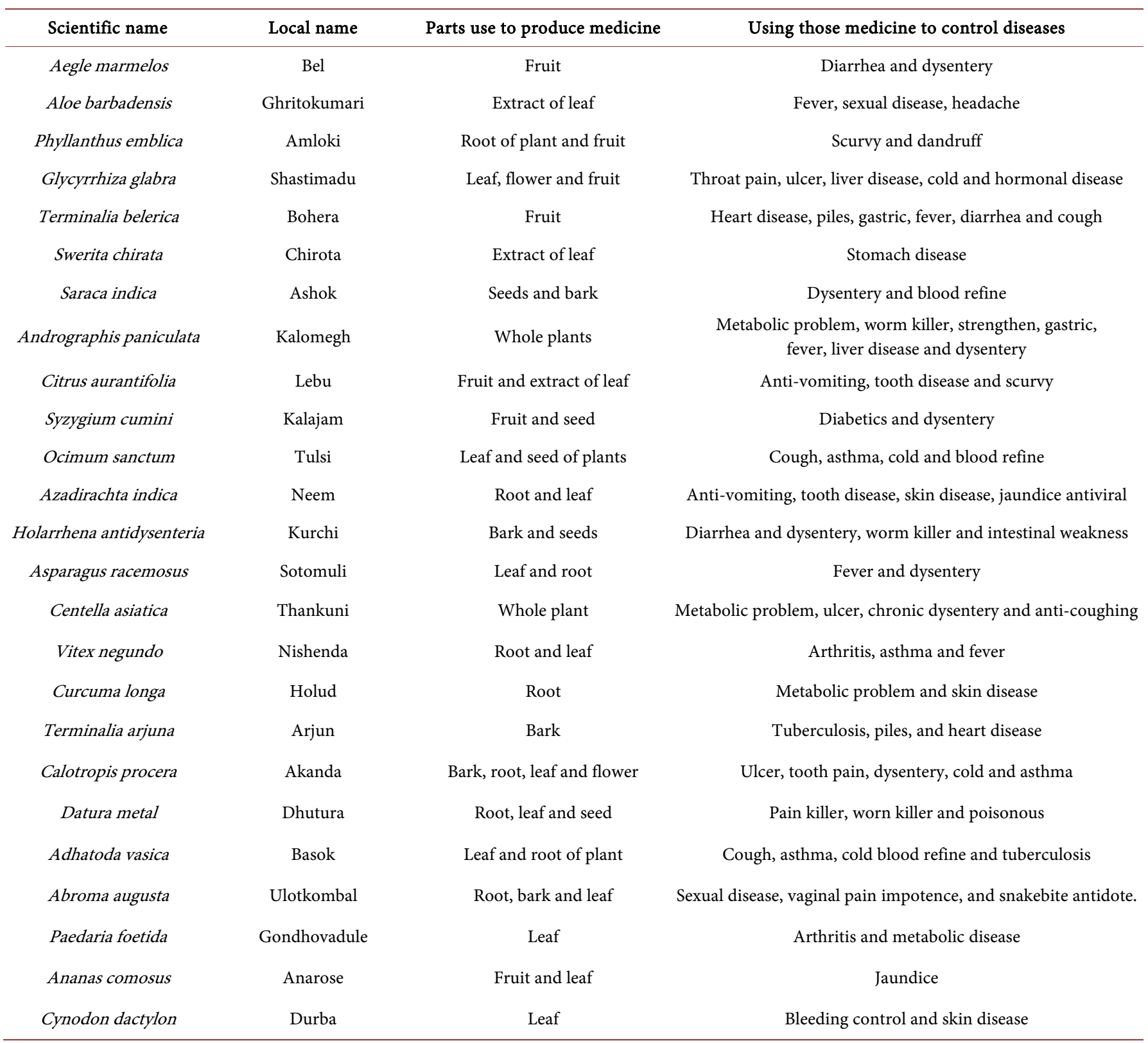

\subsection{Endangered Plant in the Study Area}

There are a number of endangered medicinal plants have been identified in the study area. Some of them are presented in the Table 6.

\section{Executive Summary}

It is established that medicinal plant and their sustainable use can cure disease, boost immunity and ensure better health of people of Bangladesh. Northern part of Bangladesh is rich in useful medicinal plants with a variety of medicinal plants. A total of 85 medicinal plants species belonging to 46 plant families were identified in the study area. 
Table 4. Formulation of the medicine from the medicinal plants and their uses.

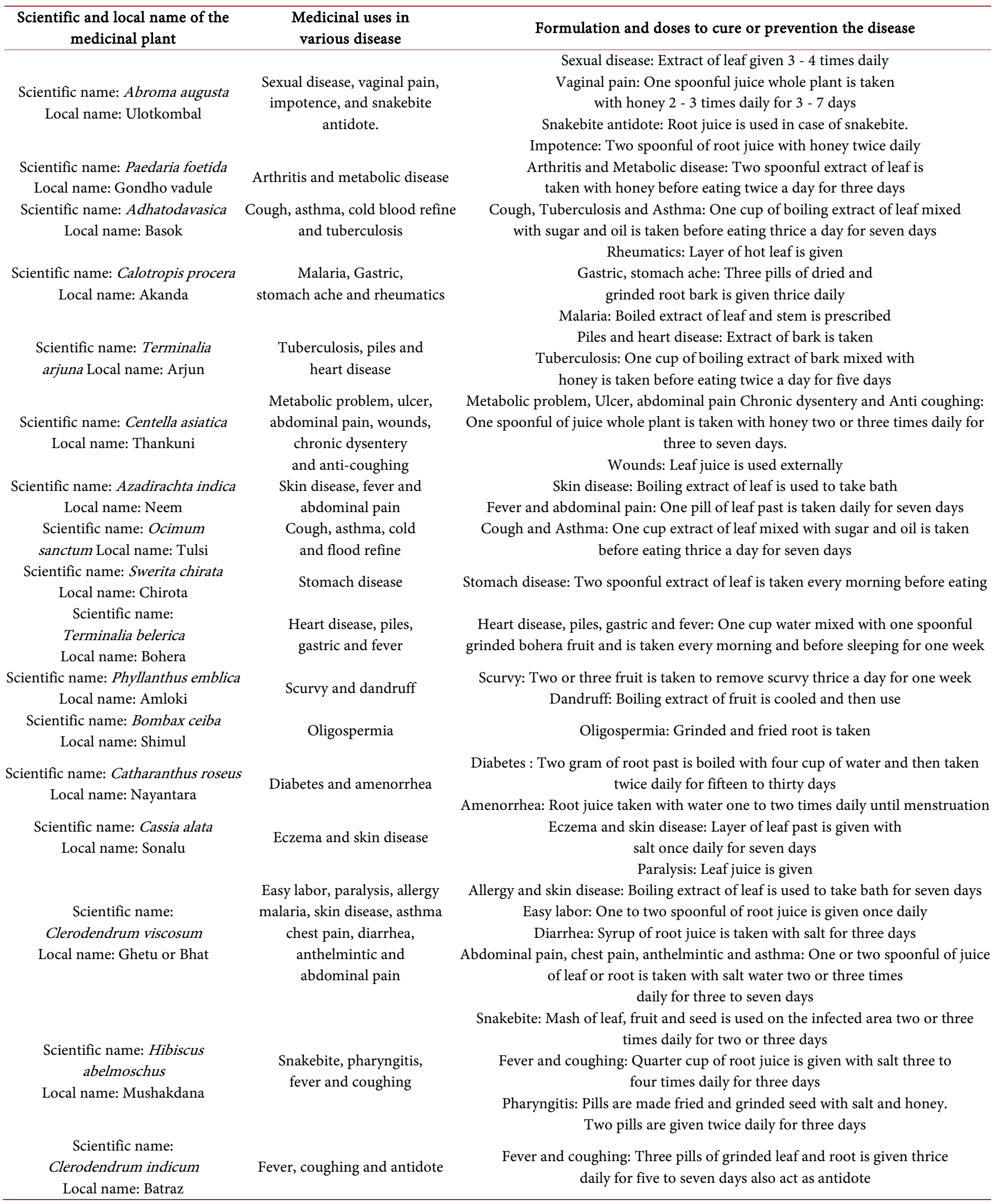


Table 5. List of the nearly extinct medicinal plants in the study area.

\begin{tabular}{cc}
\hline Plant group & Local name \\
\hline Plain and crop land plant & Sadamorong, Sialkata, Kukra, Dondokolos, Kulekhari, Kulomegis, \\
Noapata, Panicula, Futkikusumukul & Indrojob, Mohavringoraj,Chalta, Roktodron, Pitraj, Dumur, Bishfall, \\
Harrounding the path of home & Hazbli, Nisinda \\
\hline
\end{tabular}

Table 6. List of endangered plant in the study area.

\begin{tabular}{cccc}
\hline Scientific name & Local name & Scientific name & Local name \\
\hline Andrographis paniculata & Kalomegh & Dioscorea prazeri & Mati alu \\
Paedaria foetida & Gondhovadule & Terminalia citrine & Horitoki \\
Amomum costatum & Bengal cardamom & Zingiber roseum & Bilati ada \\
\hline
\end{tabular}

Different parts of the plants are used as medicinal purposes. The effects of climatic change are apparent within ecosystems around the world, including medicinal and aromatic plant populations. Due to climatic changes medicinal and aromatic plants in the study area face challenges and local plants and plants genetic diversity losses. In the study area found nearly extinct 18 species and 6 endangered species Table 5 and Table 6. Already extreme weather events impact the availability and supply of medicinal and aromatic plants on the global market and future increases in extreme weather are likely to negatively affect medicinal and aromatic plant yields even further. As a result research is emerging to protect the endangered medicinal and aromatic plants from the climate change effects. Although climate change may not currently represent the biggest threat to medicinal and aromatic plants, but it has the potential to become a much greater threat in future decades. The rural poor people of the world especially the developing countries likely the northern part of Bangladesh depends on medicinal plants not only for health care but also for source of income. The study concerns medicinal plants harvested for their essential use for oils, medicinal, fragrance, culinary and other daily purposes in the northern part of Bangladesh as well as the rural community in Bangladesh and their threat to climate change. The present study however, therefore refers all such plants under the widely used acronym MAPs in Bangladesh.

\section{Conclusion}

The potential loss of medicinal and aromatic plant species from effects of climate change is likely to have major ramifications on the livelihoods of large numbers of vulnerable populations across the world. Although climate change is more threats for medicinal and aromatic plants but the effects of climate change on medicinal plants has not been well studied. As this situation unfold climate change effects on medicinal plants may become a more pressing issue for the herbal community, users, producer and medicinal and aromatic plant species. An improved knowledge of climate change effects on medicinal plants responsible for such changes requires intensive and conti- 
nuous field measurements at representative sites. Further research on this field and chemical production efficiency of threatened medicinal plants under climate change scenario is essential for developing conservation strategies of agro-technologies for cultivation.

\section{References}

[1] Singh, J.S. (2002) The Biodiversity Crisis, A Multifaceted Review. Current Science, 82, 638.

[2] Anthony, B.C., Shanley, P. and Laird, S. (2008) Health, Habitats and Medicinal Plant Use. 35.

[3] Sarangzai, A.M., Ahmed, A. and Laghari, S.A. (2013) Traditional Uses of Some Useful Medicinal Plants of Ziarat District Balochistan, Pakistan. FUUAST Journal of Biology, 3, 101 107.

[4] Tangjitman, K., Wongsawad, C., Winijchaiyanan, P., Sukkho, T., Kamwong, K., Pongamornkul, W. and Trisonthi, C. (2013) Traditional Knowledge on Medicinal Plant of the Karen in Northern Thailand: A Comparative Study. Journal of Ethnopharmacology, 150, 232-243. http://dx.doi.org/10.1016/j.jep.2013.08.037

[5] Gadgil, M. (1996) Documenting Diversity: An Experiment. Current Science, 70, 36.

[6] Trivedi, M., Berry, P.M., Morecroft, M.D. and Dawson, T.P. (2008) Spatial Scale Affects Bio Climate Model Projections of Climate Change Impacts on Mountain Plants. Global Change Biology, 14, 1089-1103. http://dx.doi.org/10.1111/j.1365-2486.2008.01553.x

[7] Willis, K.J. and Whittaker, R.J. (2002) Species Diversity Scale Matters. Science, 295, 12451248. http://dx.doi.org/10.1126/science.1067335

[8] Barbosa, J.P.R.A.D., Rambal, S., Soares, A.M., Mouillot, F., Nogueira, J.M.P. and Martins, G.A. (2012) Plant Physiological Ecology and the Global Changes. Cienciae Agrotecnologia, 36, 253-269. http://dx.doi.org/10.1590/s1413-70542012000300001

[9] Sandel, B. and Svenning, J.C. (2013) Human Impacts Drive a Global Topographic Signature in Tree Cover. Nature Communications, 4. http://dx.doi.org/10.1038/ncomms3474

[10] IPCC (2013) Climate Change 2013: The Physical Science Basis. Contribution of Working Group I to the Fifth Assessment Report of the Intergovernmental Panel on Climate Change. In: Stocker, T.F., Qin, D., Plattner, G.K., Tignor, M., Allen, S.K., Boschung, J., Nauels, A., Xia, Y., Bex, V. and Midgley, P.M., Eds., Cambridge University Press, Cambridge and New York, 1535.

[11] Guisan, A. and Thuiller, W. (2005) Predicting Species Distribution: Offering More than Simple Habitat Models. Ecology Letters, 8, 993-1009. http://dx.doi.org/10.1111/j.1461-0248.2005.00792.x

[12] Wang, X.Y., Huang, X.L., Jiang, L.Y. and Qiao, G.X. (2009) Predicting Potential Distribution of Chestnut Phylloxerid (Hemiptera: Phylloxeridae) Based on GARP and Maxent Ecological Niche Models. Journal of Applied Entomology, 134, 45-54. http://dx.doi.org/10.1111/j.1439-0418.2009.01447.x

[13] Babar, S., Amarnath, G., Reddy, C.S., Jentsch, A. and Sudhakar, S. (2012) Species Distribution Model: Ecological Explanation and Prediction of an Endemic and Endangered Plant Species (Pterocarpus Santalinus L.F.). Current Science, 102, 1157-1165.

[14] Skov, F. and Svenning, J.C. (2004) Potential Impact of Climatic Change on the Distribution of Forest Herbs in Europe. Echography, 27, 366-380. http://dx.doi.org/10.1111/j.0906-7590.2004.03823.x

[15] Dullinger, S., Gattringer, A., Thuiller, W., Moser, D., Zimmermann, N.E., Guisan, A., 
Willner, W., lutzar, C., Leitner, M., Mang, T., Caccianiga, M., Dirnböck, T., Ertl, S., Fischer, A., Lenoir, J., Svenning, J.C., Psomas, A., Schmatz, D.R., Silc, U., Vittoz, P. and Hülber, K. (2012) Extinction Debt of High-Mountain Plants under Twenty First-Century Climate Change. Nature of Climate Change, 2, 619-622. http://dx.doi.org/10.1038/nclimate1514

[16] Keutgen, N., Chen, K. and Lenz, F. (1997) Responses of Strawberry Leaf Photosynthesis, Chlorophyll Fluorescence and Macronutrient Contents of Elevated $\mathrm{CO}_{2}$. Journal of Plant Physiology, 150, 395-400.

[17] Thomas, C.D., Cameron, A., Green, R.E, Bakkenes, M., Beaumont, L.J., Collingham, Y.C, Erasmus, B.F.N., De Siqueira, M.F., Gringer, A., Hannah, L., Hughes, L., Huntley, B., Van Jaarsveld, A.S., Midgley, G.F., Miles, L., Ortega-Huerta, M.A., Peterson, A.T., Phillips, O.L. and Williams, S.E. (2004) Extinction Risk from Climate Change. Nature, 427, 145-148.

[18] Roy, S.K. and Sarker, S.C. (2016) Integration of Remote Sensing Data and GIS Tools for Accurate Mapping of Flooded Area of Kurigram, Bangladesh. Journal of Geographic Information System, 8, 184-192. http://dx.doi.org/10.4236/jgis.2016.82017

[19] Cotton, C.M. (1996) Ethno Botany: Principles and Application. Wiley, United States.

\footnotetext{
Submit or recommend next manuscript to SCIRP and we will provide best service for you:

Accepting pre-submission inquiries through Email, Facebook, LinkedIn, Twitter, etc. A wide selection of journals (inclusive of 9 subjects, more than 200 journals)

Providing 24-hour high-quality service

User-friendly online submission system

Fair and swift peer-review system

Efficient typesetting and proofreading procedure

Display of the result of downloads and visits, as well as the number of cited articles

Maximum dissemination of your research work

Submit your manuscript at: http://papersubmission.scirp.org/
} 